\title{
PATIENT MOBILITY DIRECTIVE: ONE STEP FORWARD OR TWO STEPS BACK FOR CROSS-BORDER HEALTHCARE?
}

\author{
Tomislav Sokol, Ljerka Mintas Hodak, Ana Abramović*
}

Summary: The European Parliament and the Council of the European Union adopted on 9 March 2011 the Directive on the application of patients' rights in cross-border healthcare. This Directive emerged as a result of the Court of Justice's jurisprudence on social security coverage of healthcare obtained outside the Member State where the patient has social security protection. The aim of this paper is to investigate the Directive and determine whether it will add (once transposed into national legal systems) to the current set of patient entitlements and make it easier for patients to obtain socially covered healthcare outside the state of social protection, and to discuss the Directive's application in Croatia once the country joins the EU. The paper analyses the Patient Mobility Directive by focusing on the issue of whether the Directive actually contributes to patient mobility in the EU and also its relationship with national social security legislation, especially in Croatia. The paper argues that the Patient Mobility Directive's impact on the actual movement of patients across borders might prove to be counterproductive in some areas, due to its limiting certain entitlements to access socially covered healthcare abroad. On the other hand, the Directive will also add to some patients' entitlements in accessing healthcare abroad and improve (from the patients' point of view) certain aspects of the overall framework for obtaining cross-border healthcare. Therefore, the Directive's impact in terms of facilitating patients' ability to obtain socially covered healthcare outside the Member State of social protection remains ambivalent.

\section{Introduction}

A body of case law has been established in recent years by the European Court of Justice concerning freedom to receive healthcare treatment outside one's state of social protection (the competent state), based on the internal market free movement rules of the Treaty on the Functioning of the European Union (hereinafter TFEU). The crucial issue this

\footnotetext{
* Tomislav Sokol, PhD researcher, KU Leuven Institute for Social Law and Lecturer at the Zagreb School of Economics and Management; Ljerka Mintas Hodak, Professor at the Zagreb School of Economics and Management; Ana Abramović, Teaching Assistant at the Zagreb School of Economics and Management.
} 
case law touches upon is whether such healthcare treatment should be paid for by the state of protection, and under what conditions. The approach of the Court has placed the emphasis on giving patients additional possibilities of cover compared to the already existing regulations on the co-ordination of social security systems that have regulated the field for decades. These judgments have also created certain ambiguities concerning different aspects of the described cross-border healthcare, with several problems hampering patients' free movement.

The case law and its casuistic approach made it necessary to develop a coherent legal instrument to clarify patients' rights when accessing healthcare abroad. As a result of this necessity, the Directive on the application of patients' rights in cross-border healthcare (hereinafter the Patient Mobility Directive) entered into force on 24 April 2011. ${ }^{1}$ The Directive's purpose was to codify the case law. In addition, this piece of secondary EU legislation also regulates certain aspects of cross-border healthcare not defined by the case law. The described development is significant from the Croatian perspective, because of the country's approaching accession to the Union and the need to adapt its legal framework to EU rules.

The aim of the paper is to investigate the Patient Mobility Directive from the viewpoint of the patient and his/her rights, and to determine whether these rights have been strengthened or weakened (or neither) by the new Directive when compared to the co-ordination regulations and case law applying the Treaty, and also how the Directive will influence Croatian regulation of healthcare obtained abroad once the country joins the Union. For the purpose of this article, the notion of 'healthcare' is defined as including all activities aimed at restoring and maintaining health in the best possible way, soothing pain and making health disorders more bearable by any other means. Patient entitlements are understood as the legal possibilities for patients to access socially covered (essentially state-funded) healthcare outside the Member State in which they are socially protected (whose social security healthcare system they are a subject of).

The paper begins with the description of the Patient Mobility Directive, describing its most important provisions, and is separated into two sections. The first deals with the rules on social security coverage of healthcare treatment obtained outside the patient's state of social protection, which to a certain extent represent a codification of the case law of the Court of Justice. The second deals with the Directive's provisions which do not codify existing case law, but which represent a new de-

\footnotetext{
1 Directive 2011/24/EU of the European Parliament and of the Council of 9 March 2011 on the application of patients' rights in cross-border healthcare [2011] OJ L88/45.
} 
velopment, improving patients' access to cross-border healthcare within the EU.

The subsequent section first discusses the aspects of the Directive which represent a step forward in terms of possibilities for patients to access socially covered healthcare outside their state of social protection. It then discusses the aspects of the Directive which represent a step backwards in these terms. Finally, an analysis of the Croatian legal framework is used to highlight the positive and negative sides of the Directive regarding patients' opportunities to access socially covered cross-border healthcare.

\section{The Patient Mobility Directive}

\subsection{Codification of reimbursement rules?}

Since the beginning of the integration process, cases of people accessing socially covered healthcare outside their state of social security protection have been regulated by the regulations on co-ordination of social security systems, in order to facilitate the free movement of persons (initially only the economically active). ${ }^{2}$ This system has been sig-

2 Regulation (EEC) 3 of the Council of 25 September 1958 on social security for migrant workers [1958] OJ 30/561 (originally: Réglement 3 concernant la sécurité sociale des travailleurs migrants, last amended by Règlement (CEE) $n^{\circ} 419 / 68$ du Conseil, du 5 avril 1968, modifiant et complétant certaines dispositions des règlements $\mathrm{n}^{\circ} 3$ et 4 concernant la sécurité sociale des travailleurs migrants OJ L87/1); succeeded by Regulation (EEC) $1408 / 71$ of the Council of 14 June 1971 on the application of social security schemes to employed persons and their families moving within the Community [1971] OJ L149/2, last amended by Regulation (EC) 592/2008 of the European Parliament and of the Council of 17 June 2008 amending Council Regulation (EEC) No 1408/71 on the application of social security schemes to employed persons, to self-employed persons and to members of their families moving within the Community [2008] OJ L177 / 1 (hereinafter Regulation 1408/71); currently regulated by Regulation (EC) 883/2004 of the European Parliament and of the Council of 29 April 2004 on the coordination of social security systems [2004] OJ L166/1, last amended by Regulation (EU) 465/2012 of the European Parliament and of the Council of 22 May 2012 amending Regulation EC No 883/2004 on the coordination of social security systems and Regulation (EC) No 987/2009 of the European Parliament and of the Council laying down the procedure for implementing Regulation (EC) No 883/2004 [2012] OJ L149/4 (hereinafter Regulation 883/2004) and Regulation (EC) 987/2009 of the European Parliament and of the Council of 16 September 2009 laying down the procedure for implementing Regulation (EC) 883/2004 on the coordination of social security systems [2009] OJ L284/1, last amended by Regulation (EU) 465/2012 of the European Parliament and of the Council of 22 May 2012 amending Regulation EC No 883/2004 on the coordination of social security systems and Regulation (EC) No 987/2009 of the European Parliament and of the Council laying down the procedure for implementing Regulation (EC) No 883/2004 [2012] OJ L149/4 (hereinafter Regulation 987/2009). See also F Marhold, 'Modernisation of European Coordination of Sickness Benefits' (2009) 11 European Journal of Social Security 119; F Pennings, 'Introduction: Regulation 883/2004 - The Third Coordination Regulation in a Row' (2009) 11 European Journal of Social Security 3; Y Jorens and F Van Overmeiren, 'General Principles of Coordination in Regulation 883/2004' (2009) 11 European Journal of 
nificantly affected by the European Court of Justice, which since 1998 has rendered several judgments dealing with patients accessing socially covered healthcare outside their state of social protection (mainly dealing with planned healthcare, when a person travels abroad for the specific purpose of obtaining healthcare, ${ }^{3}$ but also dealing with unplanned healthcare in certain instances). ${ }^{4}$ These judgments have been based on the Court directly applying the free movement provisions of the Treaty in the given area (mostly the free movement of services). Since the case law has been covered in detail by the legal literature, this paper will not engage in a further analysis of the Court's jurisprudence. ${ }^{5}$ Instead, the

Social Security 47; P Schoukens and D Pieters, 'The Rules within Regulation 883/2004 for Determining the Applicable Legislation' (2009) 11 European Journal of Social Security 81.

3 Case C-120/95 Nicolas Decker v Caisse de Maladie des Employés Privés [1998] ECR I-1831 on free movement of goods; Case C-158/96 Raymond Kohll $v$ Union des Caisses de Maladie [1998] ECR I-1931; Case C-368/98 Abdon Vanbraekel and Others $v$ Alliance nationale des mutualités chrétiennes (ANMC) [2001] ECR I-5363; Case C-157/99 B.S.M. Geraets-Smits $v$ Stichting Ziekenfonds VGZ and HTM Peerbooms $v$ Stichting CZ Groep Zorgverzekeringen [2001] ECR I-5473; Case C-385/99 VG Müller-Fauré v Onderlinge Waarborgmaatschappij OZ Zorgverzekeringen UA and EEM van Riet $v$ Onderlinge Waarborgmaatschappij ZAO Zorgverzekeringen [2003] ECR I-4509; Case C-56/01 Patricia Inizan v Caisse primaire d'assurance maladie des Hauts-de-Seine [2003] ECR I-12403; Case C-496/01 Commission of the European Communities v French Republic [2004] ECR I-2351; Case C8/02 Ludwig Leichtle v Bundesantstalt für Arbeit [2004] ECR I-2641; Case C-372/04 The Queen on the application of Yvonne Watts $v$ Bedford Primary Care Trust, Secretary of State for Health [2006] ECR I-4325; Case C-466/04 Manuel Acereda Herrera v Servicio Cántabro de Salud [2006] ECR I-5341; Case C-444/05 Aikaterini Stamatelaki v NPDD Organismos Asfaliseos Eleftheron Epangelmation (OAEE) [2007] ECR I-3185; Case C-512/08 European Commission v French Republic [2010] ECR I-8833; Case C-173/09 Georgi Ivanov Elchinov v Natsionalna zdraunoosiguritelna kasa [2011] ECR I-8889; Case C-490/09 European Commission v Grand Duchy of Luxembourg [2011] ECR I-247; Case C-255/09 European Commission v Portuguese Republic (ECJ 27 October 2011).

4 Case C-211/08 European Commission v Kingdom of Spain [2010] ECR I-5267.

5 See, for instance, P Cabral, 'Cross-border Medical Care in the European Union: Bringing down a First Wall' (1999) 24 EL Rev 387; P Cabral, 'The Internal Market and the Right to Cross Border Medical Care' (2004) 29 EL Rev 673; M Cousins, 'Patient Mobility and National Health Systems' (2007) 34 Legal Issues of Economic Integration 183; M Flear, 'Case C-385/99 V. G. Müller-Fauré v. Onderlinge Waarborgmaatschappij O.Z. Zorgverzekeringen U.A. and E.E.M van Riet v. Onderlinge Waarborgmaatschappij Z.A.O. Zorgverzekeringen, Judgement of the Court of 13 May 2003' (case note) (2004) 41 CML Rev 209; SL Greer, 'Migration of Patients and Migration of Power: Politics and Policy Consequences of Patient Mobility in Europe' (2009) 26 Wisconsin International Law Journal 908; VG Hatzopoulos, 'Killing National Health and Insurance Systems but Healing Patients? The European Market for Health Care Services after the Judgements of the ECJ in Vanbraekel and Peerbooms' (2002) 39 CML Rev 683; V Hatzopoulos, 'Health Law and Policy: The Impact of the EU' in G de Burca (ed), EU Law and the Welfare State: In Search of Solidarity (OUP 2005); A Kaczorowska, 'A Review of the Creation by the European Court of Justice of the Right to Effective and Speedy Medical Treatment and its Outcomes' (2006) 12 European Law Journal 345; K Lenaerts and T Heremans 'Contours of a European Social Union in the Case-Law of the European Court of Justice' (2006) 2 European Constitutional Law Review 101; C Newdick, 'Citizenship, Free Movement and Health Care: Cementing Individual Rights by Corroding Social Solidarity' (2006) 43 CML Rev 1645; C Newdick, 'Disrupting the Community: Saving 
case law will be mentioned to the extent necessary to explain the actual contribution of the Directive to patients' rights and possibilities to access socially covered healthcare outside the competent state.

The case law has created the necessity for codification into a coherent and transparent legal framework. This endeavour has had to balance patients' rights to cross-border healthcare with the historical competences of Member States, different healthcare models and protection of the financial stability of national social security systems. ${ }^{6}$ Within this balancing exercise, it has been necessary to find solutions to the described problems emanating from the case law.

The Patient Mobility Directive was adopted on the basis of TFEU article 114 (former EC Treaty article 95) on the harmonisation of the internal market, through ordinary legislative procedure, and TFEU article 168 (former EC Treaty article 152), according to which 'a high level of human health protection shall be ensured in the definition and implementation of all Union policies and activities.' Adoption took place almost three years after the initial proposal by the Commission, which shows the complexity and political sensitivity of the subject matter. ${ }^{7}$

The use of the above-mentioned Treaty provisions is logical, since the Directive is based on the applicability of the internal market Treaty provisions to social security cover of cross-border healthcare. The use of the legal basis also demonstrates that cross-border healthcare does not fall under the complementary EU competences, as one might conclude after reading TFEU articles 153 and 168 in conjunction with TFEU ar-

Public Health Ethics from the EU Internal Market', in JW van de Gronden, E Szyszczak, U Neergaard and M Krajewski (eds), Health Care and EU Law (TMC Asser Press 2011); C Newdick The European Court of Justice, Trans-National Health Care, and Social Citizenship: Accidental Death of a Concept?' (2009) 26 Wisconsin International Law Journal 844; H Nys, 'Comparative Health Law and the Harmonization of Patients' Rights in Europe' (2001) 8 European Journal of Health Law 317; F Pennings, 'The Cross-border Health Care Directive: More Free Movement for Citizens and more Coherent EU Law?' (2011) 13 European Journal of Social Security 424; JW van de Gronden, 'Cross-Border Health Care in the EU and the Organization of the National Health Care Systems of the Member States: The Dynamics Resulting from the European Court of Justice's Decisions on Free Movement and Competition Law' (2009) 26 Wisconsin International Law Journal 705; AP Van der Mei, 'Cross-border Access to Healthcare and Entitlement to Complementary "Vanbraekel reimbursement”' (2011) 36 EL Rev 431; AP Van der Mei, 'Cross-Border Access to Health Care within the European Union: Recent Developments in Law and Policy' (2003) 10 European Journal of Health Law 369.

6 S de La Rosa, 'The Directive on Cross-border Healthcare or the Art of Codifying Complex Case Law' (2012) 49 CML Rev 15, 18.

7 Commission (EC), 'Proposal for a Directive of the European Parliament and of the Council on the application of patients' rights in cross-border health care' COM (2008) 414 final, 02 July 2008 (hereinafter Original Proposal). The Patient Mobility Directive must be transposed into Member States' legislation by 25 October 2013. See Patient Mobility Directive (n 1) art21. 
ticles 4 and 6, but instead under the internal market competence, which is shared between the Union and the Member States according to TFEU article 6 (the same holds true for the aspects of cross-border healthcare covered by the co-ordination regulations, which are also based on internal market Treaty provisions).

The Directive's personal scope of application includes those persons who are subject to EU social security co-ordination, including persons who are not Union nationals. It also applies to third-country nationals who fulfil the conditions of the state of affiliation (the competent state) for entitlement to healthcare. ${ }^{8}$

The Directive covers cross-border healthcare, which is defined in a broad manner, without making any distinction on the basis of its private or public (social) nature. E-health, whereby the service is provided without the patient actually crossing a border to access a provider established in another Member State, is also covered. ${ }^{9}$ However, long-term care for the purpose of assisting people with daily tasks, access to and allocation of organs for transplant purposes, and public vaccination programmes against infectious diseases which are exclusively aimed at protecting the health of the population on the territory of a Member State and which are subject to specific planning and implementation measures, are not covered by the Directive. ${ }^{10}$

It must be emphasised that the co-ordination rules dealing with healthcare include long-term care within their scope of application, while the case law concerning the application of the Treaty's free-provision-of-services rules on long-term care is rather ambiguous. However,

\footnotetext{
8 Patient Mobility Directive (n 1) arts 3 and 7. The co-ordination rules apply to Member State nationals; third-country nationals residing and moving within the EU (except Denmark, while the old rules apply to the UK); stateless persons and refugees residing and moving within the EU; their family members and survivors. The co-ordination rules also apply to survivors (of persons who have been subject to a Member State's legislation) who are Member State nationals, stateless persons or refugees residing in a Member State. See to this effect Council Regulation (EC) 859/2003 of 14 May 2003 extending the provisions of Regulation (EEC) No 1408/71 and Regulation (EEC) No 574/72 to nationals of third countries who are not already covered by those provisions solely on the ground of their nationality [2003] OJ L124/1; Regulation (EU) 1231/2010 of the European Parliament and of the Council of 24 November 2010 extending Regulation (EC) No 883/2004 and Regulation (EC) No 987/2009 to nationals of third countries who are not already covered by these Regulations solely on the ground of their nationality [2010] OJ L344/1; and Regulation $883 / 2004$ (n 2) art 2.

9 See Patient Mobility Directive (n 1) arts 3 and 7 and the Preamble to the Patient Mobility Directive (n 1) para 26. Healthcare is defined as "health services provided by health professionals to patients to assess, maintain or restore their state of health, including the prescription, dispensation and provision of medicinal products and medical devices'.

10 Patient Mobility Directive (n 1) art 1(3); Patient Mobility Directive (n 1) Chapter IV (arts 10-15).
} 
since remuneration in the state of treatment is the crucial criterion for the applicability of the free movement of services (when a patients pays the foreign healthcare provider directly for the treatment, and claims reimbursement from the competent state), there is no reason why longterm care should generally be excluded from the application of the Treaty rules, when remuneration (actual payment for the treatment in question) exists. ${ }^{11}$

It seems that the Patient Mobility Directive does not apply to cases where a person obtains (health)care while residing (without a foreseeable limit to the duration of that residence) outside the state of affiliation. This conclusion is based on the fact that free-movement-of-services rules are not applicable to the described residence situations, according to the Court of Justice, to whose jurisprudence the Directive refers. ${ }^{12}$ Since TFEU article 114 can only be used to harmonise the internal market, and is not applicable to the free movement of persons according to TFEU article 114(2), it can be argued that this legal basis could not be used to adopt measures relating to healthcare obtained in a state of residence outside the state of affiliation mentioned above. It seems that the Patient Mobility Directive is applicable to cases where a person obtains healthcare while staying temporarily outside the state of affiliation, since no explicit distinction is made by the provision of the Patient Mobility Directive between planned and unplanned healthcare.

The Member State of affiliation is defined as the state which is competent to give prior authorisation for obtaining socially covered healthcare in another Member State under the co-ordination rules. In the case that no Member State is competent for third-country nationals on the basis of the co-ordination rules, the Member State of insurance or the Member State granting the right to sickness benefits will be the state of affiliation. ${ }^{13}$ Since, according to Regulation 883/2004, planned healthcare which is obtained by a pensioner in a Member State which is not his/her state of residence is covered by the state of residence if that

\footnotetext{
11 Regulation 883/2004 (n 2) art 1(va); See also Pennings (n 5) 438, Case C-208/07 Petra von Chamier-Glisczinski $v$ Deutsche Angestellten-Krankenkasse [2009] ECR I-6095 paras 75- 77 and Case C-562/10 European Commission v Federal Republic of Germany (ECJ 12 July 2012) paras 40-63. According to the latter case, it seems the reliance on care escapes the free provision of services, at least as the latter has been applied in cases starting with Kohll (n 3). See also Case C-70/95 Sodemare SA, Anni Azzurri Holding SpA and Anni Azzurri Rezzato Srl $v$ Regione Lombardia [1997] ECR I-3395 paras 23-35 concerning the right of establishment.

12 Von Chamier-Glisczinski (n 11) paras 75- 77. See also, for example, Preamble to the Patient Mobility Directive (n 1) para 8. It remains questionable whether the Directive could apply to cases where a person resides outside his/her state of affiliation while he/she exercises the right of establishment in the state of affiliation.
}

13 Patient Mobility Directive (n 1) art 3. 
state has opted for reimbursement based on fixed amounts, ${ }^{14}$ the Member State of residence provides authorisation in the described situation. ${ }^{15}$ Concerning this issue, the Patient Mobility Directive provides that:

if a Member State is listed in Annex IV to Regulation (EC) No 883/2004 and in compliance with that Regulation has recognised the rights to sickness benefits for pensioners and the members of their families, being resident in a different Member State, it shall provide them healthcare under this Directive at its own expense when they stay on its territory, in accordance with its legislation, as though the persons concerned were residents in the Member State listed in that Annex. ${ }^{16}$

Therefore, a Belgian pensioner living in Spain who obtains health treatment in Belgium (which is listed in Annex IV) will be covered by Belgium.

In addition:

if the healthcare provided in accordance with this Directive is not subject to prior authorisation, is not provided in accordance with Chapter 1 of Title III of the Regulation (EC) No 883/2004, and is provided in the territory of the Member State that according to that Regulation and Regulation (EC) No 987/2009 is, in the end, responsible for reimbursement of the costs, the costs shall be assumed by that Member State. This Member State may assume the costs of the healthcare in accordance with the terms, conditions, criteria of eligibility and regulatory and administrative formalities that it has established, provided that these are compatible with the TFEU. ${ }^{17}$

This provision could be interpreted in such a way that the costs of healthcare for a person receiving a UK pension in Spain who travels to get non-hospital treatment in the UK, will be covered by the UK, since the latter State ultimately pays for the costs of the mentioned treatment within the co-ordination framework (the fixed amounts for reimbursing Spain include these costs).

A central part of the Directive deals with reimbursement rules, which determine in which situations the state of affiliation is required to cover health treatment obtained by its socially covered patients outside its territory. The first important issue one must turn to is defining the range of covered treatments. In this sense, the Directive has incorpo-

\footnotetext{
14 Regulation 883/2004 (n 2) art 27(5).

15 Regulation 883/2004 (n 2) art 27(5).

16 Patient Mobility Directive (n 1) art 7(2).

17 Patient Mobility Directive (n 1) art 7(2) and Regulation 883/2004 (n 2) art 17-35.
} 
rated important parts of recent case law in its Preamble (paragraph 34), whereby the broad national definitions of general healthcare coverage mean that the most effective foreign treatment which falls within the ambit of the definitions must be paid for by the state of affiliation, even if it is not available on its territory. ${ }^{18}$

However, the autonomy of Member States in determining by themselves the general national basket of covered healthcare, including the right to do so not only via national statutes or statutory instruments but also at the regional or local level, has been acknowledged in the normative part of the Directive, and also that patients are only entitled to foreign health treatment which is part of the state of affiliation's package. ${ }^{19}$ Read together, these provisions may be interpreted as giving more leeway to Member States than the Court of Justice's jurisprudence.

According to the Court of Justice, patients are generally entitled to planned healthcare abroad within the range of coverage defined by the state of affiliation. However, when the state of affiliation uses broad categories (like 'normal' or 'recognised' treatments) to define the range of covered healthcare, patients are entitled to the most effective foreign treatments which may fall under these broad categories, even when these treatments are not available in the state of affiliation. There is no explicit acknowledgment of the Member States' freedom to limit the range of covered healthcare on the basis of local healthcare purchasers' decisions rather than on the basis of national-level legislation. ${ }^{20}$ According to the Directive, on the other hand, national legislation which grants an explicit or implicit entitlement to local bodies that purchase healthcare to define significant parts of the healthcare coverage by themselves, can be interpreted as lawfully limiting healthcare to those treatments which are approved by these local bodies.

The next important consideration must be given to prior authorisation. Member States may impose prior authorisation to cover healthcare (abroad) which:

(a) is made subject to planning requirements relating to the object of ensuring sufficient and permanent access to a balanced range of high-quality treatment in the Member State concerned or to the wish to control costs and avoid, as far as possible, any waste of financial, technical and human resources and:

(i) involves overnight hospital accommodation of the patient in question for at least one night; or

\footnotetext{
18 See Elchinov (n 3).

19 Patient Mobility Directive (n 1) art 7.

20 See Geraets-Smits (n 3) paras 85-98 and Elchinov (n 3) paras 63-73.
} 
(ii) requires use of highly specialised and cost-intensive medical infrastructure or medical equipment;

(b) involves treatments presenting a particular risk for the patient or the population; or

(c) is provided by a healthcare provider that, on a case-by-case basis, could give rise to serious and specific concerns relating to the quality or safety of the care, with the exception of healthcare which is subject to Union legislation ensuring a minimum level of safety and quality throughout the Union. ${ }^{21}$

Member States must notify the Commission of the categories under a). In this way, Member States have a wider set of options to impose prior authorisation under the Directive than under the case law applying the Treaty. According to the case law, prior authorisation can be imposed for non-urgent hospital treatments and for treatments involving major medical equipment. ${ }^{22}$

If we look at the possible grounds for refusing authorisation, some interesting things can be observed. There is a closed list of grounds for refusal, some of which have been mentioned by the Court (a medically justifiable time limit for the provision of healthcare), ${ }^{23}$ but some of which have not (public health risks, provider-related concerns and patient-safety risks). Provider-related concerns are especially interesting, since according to free-movement jurisprudence, providers who are established in other Member States must be given all the guarantees that are given to domestic providers by the competent state. In other words, if a provider is allowed to practise medicine in the state of treatment, it is not up to the state of affiliation (the competent state) to question that provider's adequacy. ${ }^{24}$

${ }_{21}$ Patient Mobility Directive (n 1) art 8(2).

22 See Commission v France C-512/08 (n 3) paras 27-42.

23 A Member State may refuse authorisation when "healthcare can be provided on its territory within a time limit which is medically justifiable, taking into account the current state of health and the probable course of the illness of each patient concerned', according to the Patient Mobility Directive (n 1) art 8(6).

24 A Member State may refuse authorisation when 'a) the patient will, according to a clinical evaluation, be exposed with reasonable certainty to a patient-safety risk that cannot be regarded as acceptable, taking into account the potential benefit for the patient of the sought cross-border healthcare; (b) the general public will be exposed with reasonable certainty to a substantial safety hazard as a result of the cross-border healthcare in question;(c) this healthcare is to be provided by a healthcare provider that raises serious and specific concerns relating to the respect of standards and guidelines on quality of care and patient safety, including provisions on supervision, whether these standards and guidelines are laid down by laws and regulations or through accreditation systems established by the Member State of treatment', according to the Patient Mobility Directive (n 1) art 8(6). See also Kohll (n 3) para 48. 
It should be mentioned that the wording of the provision stating the cases in which prior authorisation may not be refused differs from the wording of the provision stating the cases in which authorisation may be refused. The former provision is based on case law, while the latter reiterates the wording of the co-ordination rules dealing with the same issue. According to the case law directly applying the Treaty, prior authorisation can only be refused if the same or equally effective health treatment can be provided by domestic providers without undue delay. According to the co-ordination rules, prior authorisation must be granted when the treatment cannot be provided in the state of residence of the patient within a medically justifiable time limit, taking into account the person's current state of health and the probable course of his/her illness. Since the Court's interpretations of the Treaty and of the co-ordination rules have been aligned in this respect, there should be no major legal problem stemming from the Directive (although, the case-law-based provision of the Directive omitted the inability to carry out a professional activity as a relevant criterion, which could cause problems, since it is mentioned by the case law). ${ }^{25}$

The question remains as to whether prior authorisation can be applied in cases of unplanned healthcare (when someone is temporarily abroad for some purpose other than healthcare and breaks a leg or suffers appendicitis, for instance). Although a logical answer would be in the negative, there is a possibility that it could become necessary for a person to obtain healthcare which does not have to be provided right away while temporarily staying abroad in order to finish a semester of studying abroad, for example. Could prior authorisation be imposed in these cases? Under the case law applying the Treaty, the answer is no, and also under the co-ordination regulations. ${ }^{26}$ However, the Directive is not clear on this issue. As co-ordination regulations remain applicable, the Directive's limitations may be avoided by patients by simply not opting for the procedure prescribed by the Directive, since the Directive applies without prejudice to co-ordination regulations and does not affect patients' entitlements stemming from co-ordination concerning unplanned healthcare. ${ }^{27}$

\footnotetext{
25 See Müller-Fauré (n 3) para 90; Watts (n 3) paras 62-71; Regulation 883/2004 (n 2) art 20; Pennings (n 5) 442.

26 See Commission v Spain (n 4) paras 75-76 and Regulation 883/2004 (n 2) art 19.

27 Patient Mobility Directive (n 1) art 2 and Preamble to the Patient Mobility Directive (n 1) para 28. According to the co-ordination rules, patients are entitled to unplanned healthcare which becomes necessary in the state of stay, taking into consideration the nature of the healthcare benefits in question and the expected length of stay, (by presenting a European Health Insurance Card or EHIC). This includes benefits with the aim of "preventing an insured person from being forced to return before the end of the planned duration of stay to the competent State to obtain the treatment he/she requires. The purpose of benefits of this
} 
Member State may limit the application of the rules on reimbursement:

based on overriding reasons of general interest, such as planning requirements relating to the aim of ensuring sufficient and permanent access to a balanced range of high-quality treatment in the Member State concerned or to the wish to control costs and avoid, as far as possible, any waste of financial, technical and human resources. ${ }^{28}$

How and when Member States may have recourse to the cited provision remains unclear. The rule in question, due to its vague wording, opens up a scenario whereby different Member States may apply a wide range of different criteria to limit the application of the reimbursement rules (whatever the phrase 'limit the application' might mean). The limitation imposed by the Directive upon the Member States' autonomy to apply this provision, which might be used as a starting point for the judicial control of the Member States' transposing legislation by the Court of Justice, is that the rules in question 'shall be restricted to what is necessary and proportionate, and may not constitute a means of arbitrary discrimination or an unjustified obstacle to the free movement of goods, persons or services'. ${ }^{29}$

In terms of payment methods and applicable tariffs, the Directive mostly codifies the case law directly applying the Treaty as far as planned healthcare is concerned. The patient pays the provider directly and is reimbursed afterwards by the state of affiliation (which may also

type is to enable the insured person to continue his/her stay under safe medical conditions, taking account of the planned length of the stay.' See Regulation 883/2004 (n 2) art 19, 27(1); Decision 194 of the Administrative Commission on Social Security for Migrant Workers of 17 December 2003 concerning the uniform application of art 22(1)(a)(i) of Council Regulation (EEC) No 1408/71 in the Member State of stay [2003] OJ L104/127. See also Decision S3 of the Administrative Commission on Social Security for Migrant Workers of 12 June 2009 defining the benefits covered by arts 19(1) and 27(1) of Regulation (EC) No $883 / 2004$ of the European Parliament and of the Council and art 25(A)(3) of Regulation (EC) No 987/2009 of the European Parliament and of the Council [2010] OJ C106/40; Regulation 987/2009 (n 2) art 25(3) and Case C-326/00 Idryma Koinonikon Asfaliseon (IKA) $v$ Vasilios Ioannidis [2003] ECR I-1703, relating to Regulation 1408/71 (n 2). On being bound by the findings of the state of treatment's doctors, see Case C-145/03 Heirs of Annette Keller $v$ Instituto Nacional de la Seguridad Social (INSS), Instituto Nacional de Gestión Sanitaria (Ingesa) [2005] ECR I-2529 para 53, relating to Regulation 1408/71 (n 2) and urgent treatments. See also Regulation 1408/71 (n 2) art 22(1)a, amended by Regulation (EC) 631/2004 of the European Parliament and of the Council of 31 March 2004 amending Council Regulation (EEC) No 1408/71 on the application of social security schemes to employed persons, to self-employed persons and to members of their families moving within the Community, and Council Regulation (EEC) No 574/72 laying down the procedure for implementing Regulation (EEC) No 1408/71, in respect of the alignment of rights and the simplification of procedures [2004] OJ L100/1 art 1(1).

28 Patient Mobility Directive (n 1) art 7(9).

29 Patient Mobility Directive (n 1) art 7(11). 
pay directly). The tariffs prescribed by the legislation of the state of affiliation are applicable, and the reimbursement does not have to exceed the real price of the treatment the patient paid (unless the state of affiliation voluntarily decides to pay more). This is different from co-ordination regulations, which prescribe that both planned and unplanned healthcare is provided on the basis of the tariffs of the state of treatment as if cross-border patients are socially insured there, and give an entitlement, originally stemming from the case law, to additional reimbursement on the basis of the higher competent state's coverage in the case of planned healthcare. ${ }^{30}$ On the other hand, the entitlement to additional cover on the basis of the legislation of the state of affiliation, provided for by the Directive for unplanned healthcare, is a gain for patients when compared to the case law, which does not allow for such a possibility ${ }^{31}$ Member States (those that do not have them already, which may be the case for national health services that provide healthcare free of charge) must set up transparent, non-discriminatory and objective systems for calculating reimbursement. ${ }^{32}$

In terms of healthcare providers that the patients can access, the Directive follows the approach by the Court of Justice applying free-movement Treaty provisions. Thus, according to the Patient Mobility Directive, patients can access any provider who lawfully provides healthcare in the state of treatment. This is different when compared to the co-ordination regulations, according to which patients only access those providers who are attached (employed or contracted by) to the state of treatment's social security system. ${ }^{33}$

Travel and costs of accommodation may be reimbursed by the state of affiliation, but the Directive's normative part does not lay down an explicit duty for that state to do so, even when it covers the costs in question on its own territory (this duty is contained in the free-movement case law and has been taken over by co-ordination regulations). In this way, the legislator refrained from expressly reaffirming the case law on

30 Patient Mobility Directive (n 1) art 7(4). See also Watts (n 3) para 131; Regulation 883/2004 (n 2) arts 19-20, 27 and Regulation 987/2009 (n 2) arts 25-26(7). According to these co-ordination rules, patients only have to pay upfront if the state of treatment's patients are required to do so. In the case of unplanned healthcare, reimbursement on the basis of the competent state's tariffs is possible if the patient has agreed to this (and without agreement in the case that the state of treatment's legislation does not provide for reimbursement), and when the patient has had to pay all or part of the treatment costs.

31 See Commission $v$ Spain (n 4) paras 45-81.

32 Patient Mobility Directive (n 1) art 7(6). See also Watts (n 3) paras 74 and 133.

33 Patient Mobility Directive (n 1) arts 3 and 7. See also Regulation 883/2004 (n 2) arts 19-20 and 27. 
the issue. ${ }^{34}$ However, taking into account the Directive's Preamble (paragraph 34), which states that Member States are free to cover travel and accommodation costs for foreign treatments even when they do not cover them for domestic treatments, and the fact that free movement (which prohibits discrimination against foreign service providers) is the basis for the Directive, it can be concluded that Member States must cover travel and accommodation costs for foreign treatments when they cover them for domestic treatments.

The Directive also prescribes the requirements that authorisation and reimbursement procedures must satisfy. These do not provide concrete gains for the patients. What is especially important is that the legislator did not use the possibility of imposing explicit deadlines on the state of affiliation to reach decisions on the coverage of cross-border healthcare. ${ }^{35}$

Therefore, the Directive's rules on reimbursement deal with the issues raised by the case law but, as described in the previous paragraphs, do not completely codify the case law but contain notable differences when compared to it.

\subsection{New developments}

Apart from the reimbursement rules, the Directive contains a set of rules which do not directly correspond to the rules emphasised by the case law on patient mobility, although traces of some of them can be found in other pieces of case law (for instance, the prohibition of discrimination in terms of applicable tariffs in the state of treatment, which is visible in Ferlini). ${ }^{36}$

Firstly, the Patient Mobility Directive contains rules on the recognition of medical prescriptions by Member States. If there is authorisation for a medicinal product to be marketed on their territory, Member States must make it possible for prescriptions issued for that item in a different Member State to be dispensed on their territory according to their legislation. No restrictions concerning the recognition of individual prescriptions are allowed, except in enumerated cases. The rules on prescription recognition do not affect the Directive's reimbursement rules. ${ }^{37}$

\footnotetext{
34 Patient Mobility Directive (n 1) art 7(4). See also Watts (n 3) paras 139-140 and Regulation 987/2009 (n 2) art 26(8).

35 Patient Mobility Directive (n 1) art 9.

36 Case C-411/98 Angelo Ferlini v Centre Hospitalier de Luxembourg [2000] ECR I-8081.

37 Patient Mobility Directive (n 1) art 11(1).
} 
Secondly, the Patient Mobility Directive establishes a set of duties imposed upon the state of treatment. The state of treatment is not allowed to discriminate between domestic and foreign patients. ${ }^{38}$ However, it may limit access to healthcare on its territory on the basis of overriding reasons of general interest, to prevent an increase on domestic waiting lists because of an inflow of foreign patients. The measures in question must be necessary, proportionate, must not constitute arbitrary discrimination and must be publicised in advance. ${ }^{39}$ In terms of tariffs:

Member States shall ensure that the healthcare providers on their territory apply the same scale of fees for healthcare for patients from other Member States, as for domestic patients in a comparable medical situation, or that they charge a price calculated according to objective, non-discriminatory criteria if there is no comparable price for domestic patients. This paragraph shall be without prejudice to national legislation which allows healthcare providers to set their own prices, provided that they do not discriminate against patients from other Member States. ${ }^{40}$

It can be argued that this provision enables Member States to calculate tariffs for incoming foreign patients by using different formulas than for domestic patients, which may be to the detriment of foreign patients in some situations, but also to their advantage in others. In any case, the Patient Mobility Directive still leaves possibilities for the state of treatment to limit the access of foreign patients to its healthcare providers.

Thirdly, a significant new development concerns the right to information. According to the Patient Mobility Directive, both the state of affiliation and the state of treatment must establish contact points which will, upon request, provide patients with the relevant data on cross-border healthcare. ${ }^{41}$

In the Member State of treatment, the data includes:

information concerning healthcare providers, including, on request, information on a specific provider's right to provide services or any restrictions on its practice, information referred to in Article 4(2)(a), as well as information on patients' rights, complaints procedures and mechanisms for seeking remedies, according to the legislation of that Member State, as well as the legal and administrative options

\footnotetext{
38 Patient Mobility Directive (n 1) art 4(3).

39 Patient Mobility Directive (n 1) art 4(3) and Preamble to the Patient Mobility Directive (n 1) para 21.

40 Patient Mobility Directive (n 1) art 4(4). See also Ferlini (n 36).

41 Patient Mobility Directive (n 1) art 6.
} 
available to settle disputes, including in the event of harm arising from cross-border healthcare. ${ }^{42}$

Article 4(2)(a) deals with information concerning standards of quality and safety. In this regard, it must be stressed that the principles of universality, good quality care, equity and solidarity have found their place within the framework of the Directive. Furthermore, the state of treatment is to provide for professional liability insurance (or similar) and remedies for patients who suffer harm as a result of any healthcare obtained. ${ }^{43}$

The Member State of affiliation must provide the patient, upon request, with all the information concerning reimbursement conditions and procedures for the coverage of healthcare abroad. ${ }^{44}$

Fourthly, in addition to the right to information enabling patient choice, the Patient Mobility Directive contains important provisions on co-operation and mutual assistance between national authorities, including co-operation on standards and guidelines on quality and safety (some of the provisions are based on the EU supporting and facilitating co-operation among Member States). ${ }^{45}$ Furthermore, it explicitly mentions European reference networks, based on the voluntary participation of European healthcare providers and centres of expertise, and defines their objectives, inter alia:

a) to help realise the potential of European cooperation regarding highly specialised healthcare for patients and for healthcare systems by exploiting innovations in medical science and health technologies;

(d) to maximise the cost-effective use of resources by concentrating them where appropriate;

(h) to help Member States with an insufficient number of patients with a particular medical condition or lacking technology or expertise to provide highly specialised services of high quality. ${ }^{46}$

\footnotetext{
42 Patient Mobility Directive (n 1) art 6(3).

43 See Patient Mobility Directive (n 1) art 4.

44 Patient Mobility Directive (n 1) arts 6(4), 5(b).

45 Patient Mobility Directive (n 1) art 10. See also Patient Mobility Directive (n 1) art 15, concerning health technology assessment, as a form of Open Method of Co-ordination. On this part of the Patient Mobility Directive, see T Hervey, 'Cooperation between Health Care Authorities in the Proposed Directive on Patients' Rights in Cross-Border Healthcare' in van de Gronden, Szyszczak, Neergaard and Krajewski (n 5).

46 Patient Mobility Directive (n 1) art 12. See also Patient Mobility Directive (n 1) art 14 concerning e-health.
} 
The Commission has a role in determining a list of criteria and conditions the networks and providers must fulfil. ${ }^{47}$

It must be added that the Directive provides for the European Commission to support Member States in co-operating in the development of diagnosis and treatment capacity concerning rare diseases. This is especially to be achieved by making patients, healthcare providers and national social security healthcare institutions aware of the possibilities offered by the co-ordination rules for the referral of patients with rare diseases to other Member States, even for treatments which are not available in the state of affiliation. ${ }^{48}$

As we can see, the described provisions aim at tackling structural problems in providing healthcare at the national level. These problems particularly affect Member States in which the numbers of patients suffering from certain medical conditions do not justify the maintenance of resources to treat these conditions and those Member States which, due to economic considerations, are unable to invest resources in health care at a level that is comparable to certain other Member States. One example of a smaller Member State which already enables its patients to travel abroad to obtain healthcare treatments for which there are no national resources is Ireland. The second example of this kind of country is Croatia, which will be analysed in the following section. In addition, even the UK currently does not have the capacity to offer certain advanced healthcare treatments (this is the case with proton therapy), and refers (and funds) patients abroad to obtain such treatments. ${ }^{49}$

\section{Discussion}

\subsection{One step forward}

In terms of reimbursement social security rules, the Patient Mobility Directive adds certain patient entitlements in obtaining socially covered healthcare outside the state of social protection when compared to the preceding legal framework (co-ordination regulations and the case law directly applying the Treaty's free movement rules). The Directive also improves (for patients) the overall framework for obtaining crossborder healthcare in certain areas, like the recognition of prescriptions,

\footnotetext{
47 Patient Mobility Directive (n 1) art 12(4).

48 Patient Mobility Directive (n 1) art 13.

49 See National Specialised Commissioning Team, 'Guidance for the Referral of Patients Abroad for NHS Proton Treatment' (2011); Health Service Executive, 'Health Service Executive Treatment Abroad Scheme: E1 12 (IE) Application Form' (2012); and Ordinance on Entitlements, Conditions, and Way of Exercising Health Care Abroad (Official Gazette 50/09 to 76/12) (Pravilnik o pravima, uvjetima i načinu korištenja zdravstvene zaštite $u$ inozemstvu NN 50/09 do 76/12) (hereinafter Healthcare Abroad Ordinance 2009) art 21.
} 
the state of treatment's duties, the right to information, co-operation and reference networks.

a) In the area of unplanned healthcare, the Directive offers the possibility of obtaining healthcare under more favourable domestic rules and tariffs. Since there is no such possibility under the case law, it has already been observed that this is a rare case of Member States being willing to enhance possibilities and rights stemming from free movement when the Court is unwilling to do the same..$^{50}$ Here, the legal nature of the Directive is important. In the case that the Directive is a 'field occupying' Directive, one that provides for total harmonisation of a certain area, Member States are not permitted to use Treaty-based grounds for imposing restrictions. If the Directive is a 'minimum harmonisation' Directive, such grounds are available to the states. ${ }^{51}$ Since the Directive states that it respects national competences in organising healthcare, and taking into account the legal basis (TFE article 168) which supports the same conclusion, it seems that Member States may still use the Treaty to restrict reimbursement for unplanned healthcare. ${ }^{52}$

b) Provisions concerning prescriptions make it possible for patients to avail themselves of prescriptions issued for a medicinal product in another Member State.

c) Provisions concerning the duties of the state of treatment are a gain for patients when compared to the case law, which mostly lacks clear statements on these issues. Besides the prohibition of price discrimination, which is already present in the jurisprudence of the Court of Justice, rules whereby the state of treatment must provide information on providers and patients' rights (transparency), the rules on complaints procedures, mechanisms for seeking remedies, professional liability insurance (accountability), and also on contact points are a significant gain for patients accessing healthcare in a state other than the state of social protection. Furthermore, since it is hard to imagine these rules and principles applying only to patients from other Member States, their universal applicability (to all patients) seems logical. ${ }^{53}$

\footnotetext{
50 See Van der Mei (n 5) 439.

51 On these notions, see TK Hervey, 'If Only It Were So Simple - Public Health Services and EU Law', in M Cremona (ed), Market Integration and Public Services in the European Union (OUP 2011). See also Case C-205/07 Criminal proceedings against Gysbrechts and Santurel Inter BVBA [2008] ECR I-9947 para 33.

52 See Patient Mobility Directive (n 1) art 1.

53 Some have seen the Directive as a step forward in harmonising certain aspects of Member States' healthcare systems. See W Sauter, 'Harmonisation in Healthcare: The EU Patients' Rights Directive' (TILEC Discussion Paper 06, 2011) <http://www.nza.nl/104107/230942/ Research_paper_'Harmonisation_in_healthcare_the_EU_patients'_rights_directive'.pdf> accessed 25 January 2012. On this topic, see also G Davies, 'Legislating for Patients' Rights', in van de Gronden, Szyszczak, Neergaard and Krajewski (n 5) 205-207.
} 
d) Provisions concerning the right to information in the state of affiliation, including national contact points, are another gain for patients.

e) Provisions on co-operation and European reference networks open up possibilities for patients to profit from the Directive, which tackles the structural imbalances in healthcare provision at the national level. These problems can be relieved, for example, by cross-border contracting of healthcare, whereby social security institutions from one Member State enter into contracts with healthcare providers from another. These can, for instance, be situations where foreign providers specialise in certain treatments for which there are no capacities in the state of affiliation (like the case of the UK and proton therapy). Another example of cross-border contracting is when national institutions contract foreign providers to shorten waiting times for domestic providers with limited capacities. ${ }^{54}$ Public debate at the Union level has helped to bring these possibilities to the notice of national social security institutions. ${ }^{55}$

The European Union's role in steering processes involving several Member States, and setting them within a coherent European-wide framework, can be envisaged. In practical terms, the EU is best placed, with its capabilities to obtain enough information on different national systems and co-ordinate them, to be the driving force behind the new developments. In legal terms, the EU primarily has competence in healthcare, as demonstrated by TFEU articles 6 and 168, to support and complement Member States' actions, which is precisely the case here. The Guidelines on Block Purchasing of 2005 represent one of the steps in this direction, and the Patient Mobility Directive follows suit. Since, due to the fact that Member States retain the autonomy to define and organise their social security systems, the harmonisation of social healthcare entitlements (whereby every socially covered person within the EU would have an entitlement to the same healthcare treatments under the same conditions) seems impossible, complementing Member States' healthcare actions is something to which the EU will probably have to limit itself in the years to come. ${ }^{56}$

\footnotetext{
54 One example of the latter situation is the Irish National Treatment Purchase Fund, which used to contract healthcare providers from the UK. See to this effect National Treatment Purchase Fund, 'Annual Report 2009' (2009) 1; National Treatment Purchase Fund, 'Patient Booklet' (2004) 8; National Treatment Purchase Fund, 'Freedom of Information Guidance Manual' (2006) 17.

55 See M Wismar, W Palm, J Figueras, K Ernst and E van Ginneken (eds), Cross-border Health Care in the European Union - Mapping and Analysing Practices and Policies (WHO 2011) and A Obermaier, The End of Territoriality? The Impact of ECJ Rulings on British German and French Social Policy (Ashgate 2009).

56 See Commission of the European Communities, 'Guidelines for Purchase of Treatment Abroad' (2005) and the analysis by TK Hervey, 'New Governance Responses to Healthcare Migration in the EU: The EU Guidelines on Block Purchasing' (2007) 14 Maastricht Journal of European and Comparative Law 303.
} 
f) The mere fact that codification exists in addition to casuistic jurisprudence makes it harder for a Member State to claim that individual judgments by the Court are not applicable to it because of some unique characteristic of its system. ${ }^{57}$

Therefore, in certain aspects, the Directive facilitates patient mobility within the EU when compared to the co-ordination rules and case law directly applying the Treaty.

\subsection{One step back}

There are certain areas in which the Patient Mobility Directive may prove to be counterproductive when compared to the co-ordination regulations and case law, in the sense that it reduces the entitlements of patients to obtain socially covered healthcare outside the state of social protection.

a) The first area in which the Directive offers less than the preceding framework to patients concerns the range of healthcare covered. The Member States are given more leeway to define (restrict) the range of healthcare treatments they cover, when compared to the co-ordination rules and case law. It seems that the Directive allows Member States to limit the range of treatments covered not only at the level of national legislation, but also at the level of local healthcare purchasers. ${ }^{58}$ This possibility for Member States to limit their coverage is definitely a setback for patients' rights to access cross-border healthcare, and reflects the wish of Member States to protect their social policy choices (such as local commissioning of healthcare) via EU secondary legislation. ${ }^{59}$

b) Member States have a wider set of options of imposing prior authorisation under the Directive than under the case law applying the Treaty. Seemingly, the only improvement in the individual patient's position when compared to the case law is that according to the Directive, a treatment which is a hospital treatment, but which does not involve overnight accommodation, does not warrant prior authorisation. However, according to the case law, 'services provided in a hospital environment but that could also be provided by a practitioner in his surgery or in a health centre could, for that reason, be placed on the same footing as

\footnotetext{
57 See, as a particularly good example, Watts (n 3).

58 See Elchinov (n 3) paras 67-73.

59 There is an argument that national social policy cannot be equated with national constitutional identity, since policy is a variable of national government. This implies stricter scrutiny by the Court of Justice over policy choices than over Member States' fundamental constitutional choices. See to this effect S Rodin, 'National Identity and Market Freedoms after The Treaty of Lisbon' (2011), available at <http://papers.ssrn.com/sol3/papers. cfm?abstract_id=2005691> accessed 10 January 2012.
} 
non-hospital services. ${ }^{60}$ Therefore, the possibility of patients accessing hospital out-patient treatment without prior authorisation existed even before the Directive was adopted.

What is especially striking is that there is no explicit entitlement to access healthcare without waiting for prior authorisation in cases of urgency, while such entitlement exists under the Treaty and co-ordination rules (as interpreted by the Court of Justice). There is only a statement in the Preamble (paragraph 47) that the patient should receive decisions regarding cross-border healthcare within a reasonable amount of time, and that the time can be shortened due to urgency, and a provision that when deciding on requests for cross-border healthcare, urgency must be taken into account. These provisions can be interpreted in various ways. ${ }^{61}$

In addition, different Member States can have different definitions of cost-intensive medical infrastructure (in cases of which they can impose prior authorisation), depending on their national contexts. It can be argued that the lists of treatments warranting prior authorisation will be longer in Member States with comparatively fewer resources available for allocation to healthcare than in Member States with more resources at their disposal. In this way, patients from certain Member States could find themselves in a much worse position than patients from other Member States.

Thus, the provisions of the Directive can be seen as significantly limiting patients' entitlements to obtain healthcare without prior authorisation.

c) The co-ordination rules and case law provide for a smaller number of grounds on which authorisation may be refused than the Patient Mobility Directive. Additional grounds for refusal concern public health hazards, patient-safety risks and provider-related concerns. Member States can also limit the application of reimbursement rules based on overriding reasons of general interest, which leaves possibilities for various scenarios and interpretations by different Member States.

Taking all this together, it can be assumed that the Patient Mobility Directive will be mostly relevant as a legal instrument for accessing healthcare which does not require prior authorisation, depending on how the Court of Justice will interpret obvious differences between the Directive and its case law applying the Treaty on when authorisation may be imposed (namely, whether the additional grounds for imposing

60 See Commission v France C-512/08 (n 3) para 35. See also Pennings (n 5) 440-441.

61 See Elchinov (n 3) paras 43-51. See also Commission v France C-512/08 (n 3) para 27 and Patient Mobility Directive (n 1) art 9. 
authorisation will be interpreted as falling within the accepted justifications for limiting free movement). In cases in which prior authorisation is required, using co-ordination regulations provides the patients with an opportunity to obtain healthcare on the basis of the tariffs set by the state of treatment, while maintaining the entitlement to higher coverage by the competent state. Furthermore, it must be stressed that the Patient Mobility Directive, unlike the co-ordination rules, provides for direct payment upfront by the patient to the provider, a fact which favours well-off patients, and makes co-ordination more appealing to patients from less affluent Member States. ${ }^{62}$

The issue of substantial differences between the Directive and judgments applying primary law remains ambiguous, especially in those areas in which the Directive gives more leeway to the states than the case law does. If we remember that, apart from the case law applying the Treaty and Directive, there are also EU co-ordination rules which regulate the same area, it is not hard to conclude that the clarity of patients' cross-border entitlements and legal certainty suffer from the existing complex EU legal framework. When it comes to rules on reimbursement and social cover, there are now in effect three parallel legal instruments which apply to the same area: co-ordination regulations, Treaty freemovement provisions and the Patient Mobility Directive.

A logical question arises: was it possible to incorporate the changes brought about by the case law into the co-ordination regulations? Some of them actually have been incorporated (the right to additional reimbursement in accordance with the competent state's rules and also travel and accommodation costs in planned healthcare) into the co-ordination instruments. On the other hand, it is much easier to adopt a directive on the basis of TFEU article 114 than to amend the co-ordination rules, where unanimity essentially still applies through TFEU article 48 and the 'emergency brake' procedure. In terms of substance, however, spelling out all the rules on the social security cover of cross-border healthcare in a single legal instrument would have benefited patients due to the increased clarity and transparency of the framework. In any case, the Court should use its future jurisprudence to clarify outstanding issues. ${ }^{63}$

Thus, the Patient Mobility Directive's impact on the actual movement of patients across borders might prove to be counterproductive in some areas, due to limitations upon some of their entitlements to access

\footnotetext{
62 See Regulation 883/2004 (n 2) art 20 and Regulation 987/2009 (n 2) art 26(7).

63 See Regulation 987/2009 (n 2) art 26(7-8). See also E Szyszczak, 'Patients' Rights: A Lost Cause or Missed Opportunity?' in van de Gronden, Szyszczak, Neergaard and Krajewski (n 5) 125. On the emergency brake, see Commission of the European Communities, 'Treaty of Lisbon: New Cases of Qualified Majority Voting' (Council and European Council) (2007).
} 
socially covered healthcare. On the other hand, the Directive will also add to some patients' entitlements and opportunities to access healthcare abroad. Therefore, the Directive's impact in facilitating patients to obtain socially covered healthcare outside their state of social protection remains ambivalent.

\subsection{Case study: Croatia}

\subsubsection{Overview}

Croatia is an interesting example to illustrate the problems concerning the transposition and implementation of the Patient Mobility Directive. This is due to the fact that Croatia is to become a Member State a few months before the end of the transposition period, but especially because it can be used as an example of how a country which is still not an EU Member State regulates patient entitlements to obtain socially covered healthcare abroad without the EU rules. In addition, it is a relatively small country in terms of territory and population, with a per capita GDP significantly lower than the EU average, a fact that makes it vulnerable to problems in maintaining expensive human and material capacities to treat certain medical conditions, which is one of the problems the Directive deals with. ${ }^{64}$ Since the Patient Mobility Directive reimbursement rules deal with the obligations of the state of affiliation (the competent state) to cover the healthcare of its patients obtained abroad, the focus is placed on the Croatian rules covering patients socially insured in Croatia obtaining healthcare outside the country.

The system of social coverage of healthcare obtained abroad is currently regulated in Croatia through several legal instruments. The first ones are bilateral agreements on social security co-ordination concluded between Croatia and individual EU Member States. Bilateral agreements take precedence over national statutes once ratified. ${ }^{65}$ Croatia has concluded bilateral agreements, including those assumed from the former Yugoslavia, with 17 Member States of the European Union. These are: Austria, Belgium, Bulgaria, the Czech Republic, Denmark, France, Germany, Hungary, Italy, Luxembourg, the Netherlands, Poland, Romania, Slovakia, Slovenia, Sweden and the United Kingdom. ${ }^{66}$ These agreements are mutual, meaning that provisions which are applicable to Croatian (socially covered) patients accessing healthcare abroad are generally also

\footnotetext{
64 According to EUROSTAT <http://epp.eurostat.ec.europa.eu/tgm/table.do?tab=table\&i nit=1\&plugin $=1$ \&language $=$ en \&pcode $=$ tec00114 $>$ accessed on 12 September 2012 .

65 Constitution of the Republic of Croatia (Official Gazette 56/90 to 85/10) (Ustav Republike Hrvatske NN, 56/90 do 85/10) (hereinafter Croatian Constitution 1990) arts 140-141.

66 See M Rismondo, Zbirka ugovora o socijalnom osiguranju (Narodne novine 2007).
} 
applicable to foreign (socially covered) patients accessing healthcare in Croatia.

The agreements can be divided into those which cover only the nationals of countries which are parties to the agreements in question, their family members and, in some cases, refugees and stateless persons, and those which cover all persons socially insured by those countries, and their family members. The main criterion for determining the competent state is the law of the place of work or lex loci laboris. ${ }^{67}$

The legal source that generally regulates the social security coverage of healthcare in Croatia is the Compulsory Health Insurance Act of 2008 (hereinafter the Health Insurance Act of 2008). This act determines the personal scope of the application of the Croatian social security healthcare system, the range of covered healthcare in general, and the cover of health treatments obtained outside Croatia. ${ }^{68}$

Every resident of Croatia (but also foreigners granted permanent stay, except in cases in which international agreements determine otherwise; an exception also exists concerning children under 18 years of age, who are considered to be insured) is obliged to obtain social insurance with the Health Insurance Institute of Croatia (HIIC) on one of the grounds enumerated by the Health Insurance Act of 2008. These grounds include conducting a professional activity, putting Croatia somewhere in between the professional and occupational systems of social security. Healthcare is covered mainly through direct payments by the HIIC to providers, making the system a benefits-in-kind system. The range of covered healthcare is prescribed using broad notions and various criteria, which include types of medical condition (illnesses), types of patient (for instance, free-of-charge provision for persons who have not turned 18) and types of medical procedure (health treatments). ${ }^{69}$

Finally, a statutory instrument regulating healthcare abroad has been adopted by the HIIC (following the consent of the minister in charge of healthcare). The instrument must be applied in line with the relevant statutes and international agreements. These provisions deal with op-

\footnotetext{
67 The first group consists of agreements with Bulgaria, Denmark, France, Germany, Italy, Poland, Slovakia, Sweden and the United Kingdom. The second group consists of agreements with Austria, Belgium, the Czech Republic, Hungary, Luxembourg, the Netherlands, Romania and Slovenia. See Rismondo (n 66) 14.

68 Compulsory Health Insurance Act (Official Gazette 150/08 to 90/12) (Zakon o obveznom zdravstvenom osiguranju NN 150/08 do 90/12) (hereinafter Health Insurance Act 2008).

69 See Health Insurance Act 2008 (n 68) arts 3-16. See also D Pieters, Social Security: An Introduction to the Basic Principles ( ${ }^{\text {nd }}$ edn Kluwer Law International 2006) 21-22. On the definition of residence, see Residence and Stay of Citizens Act (Official Gazette 53/91 to 11/00) (Zakon o prebivalištu i boravištu građana NN 53/91 do 11/00) arts 2-4.
} 
portunities for Croatian (socially covered) patients to access healthcare outside Croatia and for it to be paid for by the HIIC. ${ }^{70}$

\subsubsection{Problems with the Patient Mobility Directive}

The first area in which the transposition of the Patient Mobility Directive in Croatia may run into problems concerns determining the range of healthcare covered, namely when accessing planned healthcare abroad. As noted, the range of healthcare covered is prescribed using broad notions and various criteria which include the types of medical condition, categories of patient and types of medical procedure. This technique opens up possibilities for Croatian patients to access the best possible healthcare anywhere in the EU (once Croatia accedes to the latter) which fit into these broad notions. The Patient Mobility Directive recognises the autonomy of Member States in determining by themselves the general national basket of covered healthcare, including the right to do so not only via national statutes or statutory instruments but also at the regional or local level. However, Croatia does not define the range of covered healthcare locally, but instead leaves it to the medical profession to define which medical treatments are recognised by medical science and are thus covered by the broad national definitions of the healthcare covered. The coverage of treatments which are recognised by medical science but not provided in Croatia is currently possible, but it remains ambiguous whether certain healthcare treatments which are recognised by the medical profession abroad, but which have never been tested or used in Croatia, are to be considered (according to the Directive) as being covered by Croatian national legislation and thus eligible to be funded when provided abroad. This is especially questionable in cases where there is no consensus within 'international medical science' regarding a certain treatment. ${ }^{71}$ Therefore, it is dubious how Croatia will interpret its obligations concerning the range of healthcare abroad it will have to cover under the Patient Mobility Directive, a lack of clarity which does not help Croatian patients obtain socially covered healthcare outside Croatia.

The second important aspect of the Patient Mobility Directive which raises ambiguities in the Croatian case concerns the possibility of imposing prior authorisation for Croatian patients accessing planned healthcare abroad. Only a small number of Croatian bilateral agreements contain provisions concerning planned healthcare. In these cases, coverage

\footnotetext{
70 Health Insurance Act 2008 (n 68) art 20 and Health Care Abroad Ordinance 2009 (n 49).

71 On this issue, see Us-2107/2008 Administrative Court of the Republic of Croatia 12 January 2011 and Us-4587/2009 Administrative Court of the Republic of Croatia 20 January 2011.
} 
is generally provided by the competent state on the basis of the state of treatment's rules and tariffs (settled between the two states), and patients can only access providers attached to the social security of the latter state. Prior authorisation is required, but can be granted afterwards if it was not requested in time for objective reasons in the cases of Germany, Hungary and Slovenia. ${ }^{72}$

Generally, prior authorisation for planned healthcare can be given for healthcare abroad for treating congenital defects, for carrying out organ transplants, and for treating malignant diseases. Authorisation can be given if treatments which are necessary cannot be provided by HIICaffiliated healthcare providers in Croatia but can be provided abroad. Exceptionally, authorisation may be granted for treatments abroad not related to the mentioned diseases. Treatments can also be provided by providers not affiliated to the state of treatment's social security system (these will not be covered under bilateral agreements). ${ }^{73}$

As noted in the section on the Patient Mobility Directive, the Directive prescribes several possibilities for Member States to impose prior authorisation. The main problem concerns treatments which are:

made subject to planning requirements relating to the object of ensuring sufficient and permanent access to a balanced range of highquality treatment in the Member State concerned or to the wish to control costs and avoid, as far as possible, any waste of financial, technical and human resources and ... require use of 'highly specialised and cost-intensive medical infrastructure or medical equipment'. ${ }^{74}$

The reason for claiming there is a problem is the fact that countries' methods of controlling costs depend on the specific national context, which implies that Croatia can have a different (wider) definition of problematic 'cost-intensive medical infrastructure' than, for instance, Germany, which has significantly more financial resources available to allocate for healthcare. The latter situation is clearly visible from the fact

\footnotetext{
72 These include agreements with Austria, Germany, Hungary, Italy, Luxembourg and Slovenia. See, for example, Agreement on Social Insurance between the Republic of Croatia and Republic of Austria (Official Gazette - International Agreements 15/97 and 13/98) (Ugovor o socijalnom osiguranju između Republike Hrvatske i Republike Austrije NN-MU, 15/97 i 13/98) (hereinafter Croatia-Austria Agreement 1997) art 11 and Agreement on Social Insurance between the Republic of Croatia and Republic of Slovenia (Official Gazette - International Agreements 16/97 and 3/98) (Sporazum o socijalnom osiguranju između Republike Hrvatske i Republike Slovenije NN-MU, 16/97 i 3/98) (hereinafter Croatia-Slovenia Agreement 1998) art 12.

73 Healthcare Abroad Ordinance 2009 (n 49) art 21. See also the Health Insurance Act 2008 (n 68) art 20.

74 Patient Mobility Directive (n 1) art 8(2).
} 
that annually most Croatian patients sent abroad are sent to Germany and Austria to obtain advanced healthcare treatments not available at home. ${ }^{75}$ Thus, the Patient Mobility Directive can be seen as allowing, and even exacerbating, differences between patients from various Member States in terms of accessing healthcare abroad, and putting Croatian patients in a comparatively worse situation when compared to patients from certain EU Member States.

The third important ambiguity of the Patient Mobility Directive that can cause problems within the Croatian context concerns the possibilities of limiting the application of reimbursement rules. As Member States can limit the application of reimbursement rules based on overriding reasons of general interest, ${ }^{76}$ various Member States can interpret the notion of 'overriding reasons of general interest' in different ways. Since the Croatian context in terms of resource allocation is significantly different when compared to several Member States, as noted in the previous paragraphs, its interpretation of the notion of 'overriding reasons of general interest' can also vary when compared to these other states, thus limiting the opportunities of Croatian patients to access healthcare abroad.

Finally, it must be emphasised that the Patient Mobility Directive favours well-off patients who are able to pay the healthcare provider upfront, and request reimbursement afterwards. Within the Croatian context, it can be assumed that Croatian patients of average means will not find it easy to obtain most advanced healthcare treatments in Germany or Austria, the countries where Croatian patients obtain most (expensive) planned healthcare treatments which are not available in Croatia. ${ }^{77}$

\subsubsection{Amending the national rules to conform with the Patient Mobility Directive}

There are certain national rules within the Croatian framework which will have to be changed once Croatia joins the EU and the Directive's transposition period expires.

The first thing that will have to be abolished is the special contribution for unplanned healthcare. Currently, the only possibility of accessing unplanned healthcare for Croatian patients outside Croatia that is covered by the HIIC exists if a special contribution has been paid by the patient, his/her employer or a third person in some cases. The pa-

\footnotetext{
75 Health Insurance Institute of Croatia, 'Izvješće o upućivanju osiguranih osoba na liječenje u inozemstvo tijekom 2010. godine' (2011).

76 Patient Mobility Directive (n 1) art 7(9).

77 See Health Insurance Institute of Croatia (n 75).
} 
tient must obtain an HIIC certificate before travelling abroad, otherwise there will be no coverage (an exception concerns business trips). The person who had to apply for the certificate pays the costs. ${ }^{78}$ This provision, which makes Croatian patients pay a special contribution in order to access socially covered healthcare abroad, can be regarded as discrimination against foreign healthcare providers when compared to domestic (Croatian) ones, and will have to be abolished.

Secondly, the current Croatian legal framework provisions that provide mostly for the coverage of emergency unplanned healthcare obtained abroad (a narrower notion than 'necessary healthcare' under EU co-ordination rules) for Croatian patients will have to be abolished. According to the statutory instrument currently in force, Croatian insured persons privately staying abroad and students and pupils studying abroad on their own account have an entitlement to emergency healthcare (also family members of persons sent abroad for work or education). The latter care includes diagnostic and therapeutic procedures necessary to eliminate a direct peril to the person's life and health. Other persons are entitled to healthcare that cannot be postponed until the patient's return to Croatian care (including family members of persons sent abroad for education or work). Some of the bilateral agreements do not contain specific provisions on coverage of unplanned healthcare abroad at all, ${ }^{79}$ while other agreements provide for coverage of emergency (urgent) healthcare to prevent danger to one's life and health. ${ }^{80}$ Under the Directive, Croatia will have to provide for coverage of wider healthcare than is currently the case, and amend national rules accordingly.

\footnotetext{
78 See Health Care Abroad Ordinance 2009 (n 49) arts 5-14. See also the Contributions Act (Official Gazette 84/08 to 22/12) (Zakon o doprinosima NN 84/08 do 22/12). According to certain bilateral agreements, the state of treatment can request a certificate afterwards. See, for example, the Administrative Agreement on the Implementation of the Agreement on Social Insurance between the Republic of Croatia and Republic of Slovenia (Official Gazette - International Agreements 5/98) (Administrativni sporazum o provedbi Sporazuma o socijalnom osiguranju između Republike Hrvatske i Republike Slovenije NN-MU, 5/98) (hereinafter Croatia-Slovenia Administrative Agreement 1998) art 6.

79 These include agreements with Bulgaria, Denmark, France and Sweden. There are certain special rules on posted workers. See, for example, Agreement on Social Insurance between the Republic of Croatia and Republic of Bulgaria (Official Gazette - International Agreements 4/04 and 7/04) (Ugovor između Republike Hrvatske i Republike Bugarske o socijalnom osiguranju NN-MU, 4/04 i 7/04) (hereinafter Croatia-Bulgaria Agreement 2004) art 8 .

80 These include agreements with Belgium, the Czech Republic, Hungary, Italy, Luxembourg, the Netherlands, Poland, Romania, Slovakia, Slovenia and the United Kingdom. See, for example, Agreement on Social Insurance between the Republic of Croatia and Republic of Hungary (Official Gazette - International Agreements 11/05 and 3/06) (Ugovor o socijalnom osiguranju između Republike Hrvatske i Republike Mađarske NN-MU, 11/05 i 3/06) (hereinafter Croatia-Hungary Agreement 2006) art 11
} 
Third, in terms of planned healthcare, the main disparity between the Croatian legal framework and the Patient Mobility Directive is the fact that, under Croatia's legal framework, prior authorisation is almost always required for Croatian (socially covered patients) to access healthcare outside its territory. ${ }^{81}$ The only exception is under certain bilateral agreements according to which the authorisation can be given afterwards if it has not been requested in time for objective reasons. Under the Patient Mobility Directive, there is a relatively wider range of possibilities to access healthcare abroad without prior authorisation (although with some ambiguities, described in the previous paragraphs), and Croatia will have to prescribe these possibilities and, thus, change the national rules on authorisation. It must also be added that according to the bilateral agreements, only providers attached to the social security of the state of treatment can be accessed on the basis of the latter state's tariffs. When the agreements are abolished, the Directive will also entitle Croatian patients to obtain healthcare according to Croatian tariffs from those healthcare providers who are not attached to the state of treatment's social security.

Croatia will also have to implement the Directive's provisions on the right to information, mutual co-operation and reference networks. Here, it is especially important to emphasise that Croatian patients are to a large extent already sent abroad if treatments which are necessary cannot be provided by HIIC-affiliated healthcare providers in Croatia but can be provided by foreign providers, which includes treatments which are recognised by medical science but which are not provided in Croatia. These are treatments for which it is not feasible to maintain national (including human) resources for various reasons. ${ }^{82}$ This situation is a strong incentive for Croatian healthcare providers to take part in the European reference networks, which are designed to help Member States with an insufficient number of patients with a particular medical condition or which are lacking in technology or expertise to provide high-quality specialised services. It is possible that if the networks really take off, certain Croatian hospitals will become centres of expertise for certain medical conditions (at least for neighbouring countries), while on the other hand Croatia will develop further routes for referring patients with other medical conditions abroad.

Finally, Croatia will have to implement the parts of the Directive which concern the duties of the state of treatment for patients coming from other Member States to obtain healthcare in Croatia. This is espe-

81 Health Care Abroad Ordinance 2009 (n 49) art 21.

82 See, for instance, Us-8248/2005 Administrative Court of the Republic of Croatia 17 April 2008. 
cially the case with the Directive's rules on prohibiting price discrimination (currently, for patients who come from countries with which no bilateral agreement has been concluded, Croatian providers may apply different prices than for persons socially insured in Croatia), ${ }^{83}$ providing information on providers, patients' rights, contact points, complaints procedures, mechanisms for seeking remedies and professional liability insurance.

\section{Conclusion}

The Patient Mobility Directive has evolved as a result of the jurisprudence of the Court of Justice, which has applied the internal market rules of the TFEU to situations in which a person accesses healthcare in a Member State which is not his/her state of social protection. However, the result of the legislative procedure has not followed the approach of the Court of Justice literally. Although, in some instances, the Directive enhances patients' rights to reimbursement of healthcare abroad (concerning unplanned healthcare) and improves the framework for patients to access healthcare abroad, the additional grounds for imposing prior authorisation, possibilities to refuse reimbursement, and additional opportunities for Member States to limit the range of covered healthcare and to limit the rules on reimbursement, significantly weaken patients' legal position and are thus counterproductive in facilitating patients' movement across national borders. Furthermore, the Directive has added to the complexity of the legal regulation of cross-border healthcare, since several parallel legal routes are now in existence covering the same area. These are the areas where the Directive's adoption may prove to be counterproductive, by making it harder for patients to obtain socially covered (reimbursed) healthcare outside their state of social protection when compared to the co-ordination rules and case law on free movement. The Court of Justice should use its future case law to clarify the relevant legal framework.

The Croatian example emphasises some of the problems stemming from the Patient Mobility Directive's provisions on the reimbursement of healthcare obtained outside one's state of social protection. These problems deal with the range of reimbursed healthcare obtained abroad, prior authorisation necessary for the patients to obtain that reimbursement and the possibilities for national authorities to limit the application of reimbursement rules in certain instances. On the other hand, Croatia's legal framework will strengthen some patients' entitlements, provided

\footnotetext{
83 See Health Insurance Institute of Croatia, 'What you should know about the usage of health care services during temporary stay in the Republic of Croatia' <http://www.hzzonet.hr/03_03_05_eng.php> accessed 20 September 2012.
} 
the Directive is correctly transposed into the national setting. Possibilities to access healthcare abroad without prior authorisation, abolishing the special contribution for treatments obtained abroad, and making Croatian healthcare providers part of the European reference networks, are some of the gains for Croatian (covered) patients from the Directive's future implementation in their country.

Finally, although the Directive's effects in terms of patients' entitlements to social cover remain ambivalent, there are some additional gains from its adoption. These gains concern a step in the direction of resolving the structural problems of national healthcare systems by means of cooperation and the Union supporting Member States' healthcare policies. In terms of these developments, the Directive provides a push in the direction of a more active EU role in the area of healthcare. It seems this Union role will, to a large extent, be present within the realm of help and guidance in complementing national healthcare policies, since Member States retain the freedom to define and organise their social security healthcare systems. 